\title{
Opóźniony rozwój mowy a nowe technologie. Doniesienia z badań
}

\section{Delayed Speech Development and New Technologies Report From a Research}

Słowa kluczowe: opóźniony rozwój mowy, nowoczesne technologie, wywiad logopedyczny, diagnoza logopedyczna

Keywords: delayed speech development, modern technologies, speech therapy questionnaire, logopedic diagnosis

\section{Streszczenie}

Artykuł prezentuje wyniki diagnozy logopedycznej małych dzieci (do lat trzech). Dla badaczki istotne było znalezienie odpowiedzi na pytanie, jaki wpływ ma nowoczesna technologia na rozwój mowy małych dzieci. Opracowany przez autorkę artykułu kwestionariusz wywiadu $\mathrm{z}$ rodzicami został poszerzony o pytania dotyczące nowoczesnych technologii. Zbadanie małych dzieci z opóźnionym rozwojem mowy oraz dzieci z mową w normie rozwojowej, jak również rozmowy z ich rodzicami pozwoliły porównać, czy i w jakim stopniu oglądanie telewizji lub filmów na telefonie, a także gry na tablecie mogą zaburzać rozwój werbalny dziecka.

\section{Abstract}

The article presents the results of a logopedic diagnosis of young children's speech (up to 3 years old). It was important for the researcher to find the answer to the question what influence modern technology has on the development of speech in young children. The original diagnostic questionnaire prepared by the author of the article has been expanded to include questions referring to modern technologies. The comparative study of young children with delayed speech development and the children who speak correctly, as well as interviews with their parents enabled the author to state whether and to what extent watching TV or videos on mobile phones and playing games on tablets can disturb verbal development of a child.

* Uniwersytet Śląski w Katowicach, Wydział Humanistyczny, Instytut Językoznawstwa, ul. Uniwersytecka 4, 40-007 Katowice, e-mail: kamila.kuros-kowalska@us.edu.pl, ORCID: https:// orcid.org/0000-0002-3618-4927. 


\section{Wprowadzenie}

Dziecko za pomocą słów porządkuje rzeczywistość, która w ten sposób staje się dla niego bardziej zrozumiała i przystępna. Nazywanie tego, co bliskie, daje poczucie bezpieczeństwa. Dziecko, które nie nazywa świata, może czuć się w nim zagubione, nie jest $\mathrm{w}$ stanie zdefiniować siebie w odniesieniu do tego, co je otacza. Jeśli dziecko nie ma kontroli nad rzeczywistością i nie jest przez nikogo rozumiane, nie czuje się pewnie. To wszystko powoduje, że może stać się ono sfrustrowane, labilne emocjonalnie czy nawet agresywne. Brak mowy „[...] w przypadkach skrajnych skazuje jednostkę na przebywanie we własnym, wyizolowanym świecie” [Grabias, 2014, s. 29].

Każdy człowiek chce wyrażać swoje potrzeby. Jeśli skutkuje to niepowodzeniem, dziecko może czuć się gorsze, a jego relacje z bliskimi osobami będą znacznie uboższe. Negatywne konsekwencje mogą pojawić się zwłaszcza w relacji rodzic - syn/córka. Problemy z komunikacją, których takie dziecko doświadcza na co dzień, mogą skutkować także tym, że nie będzie ono chciało podejmować prób porozumiewania się z innymi osobami, ponieważ łatwo się zniechęca. $Z$ drugiej strony, jeśli otrzyma nadmierne wsparcie nadopiekuńczych rodziców bądź opiekunów, którzy będą jego „tłumaczami”, nie zostanie zachęcone do podejmowania prób werbalnego ujmowania świata. Z moich doświadczeń diagnostycznych wynika, że od kilku lat pojawiają się w gabinetach logopedycznych rodzice coraz młodszych dzieci, których rozwój językowy znacznie odbiega od normy. Z pogłębionych rozmów i wywiadów z rodzicami dowiedziałam się, że najmłodsi, zanim zaczną mówić, otrzymują multimedialne gadżety (tj. telefon, tablet, telewizor, konsolę) z bajkami, aplikacjami lub grami. Są one dla nich bardzo atrakcyjne i zaczynają dominować w ich życiu nad innymi codziennymi czynnościami, a w konsekwencji odbierają chęć do jakichkolwiek aktywności związanych z wymianą myśli za pomocą słów. Pobudzanie od samego początku wyłącznie prawej półkuli mózgu powoduje, że dzieci chętniej wyrażają swoje emocje ruchami, gestami i zachowaniami, w których nie liczą się słowa. Badania naukowe [Kamińska, 2011, s. 89] dowodzą, że lewa półkula odpowiada, poza słowami, także za naśladowanie ruchów narządów artykulacyjnych, które są tak istotne w nauce mówienia.

Moim celem było przeprowadzenie badań w grupie dzieci z prawidłowym oraz opóźnionym rozwojem mowy. Kolejnym etapem było przeprowadzenie wywiadu $\mathrm{z}$ ich rodzicami, by ustalić, czy nowoczesne technologie mogą mieć wpływ na rozwój mowy. 


\section{Opóźniony rozwój mowy}

Tematem dzieci, które nie mówią, mimo posiadania słuchu w normie oraz prawidłowo rozwiniętej inteligencji, od lat zajmują się liczni badacze. Z uwagi na zróżnicowaną terminologię, w której brakuje jasnych wyznaczników w ustaleniu definicji terminu opóźnionego rozwoju mowy (alalii, niedokształcenia mowy), zagadnienie to może wydawać się nieprzejrzyste, na co zwracała uwagę już Grażyna Jastrzębowska [2003a, s. 9-36]. Zdaniem badaczki opóźniony rozwój mowy pojawia się w sytuacji, gdy kompetencje językowe dziecka nie rozwinęły się wcale lub rozwinęły niedostatecznie, by móc budować wypowiedzi, albo w sytuacji, gdy doszło do uszkodzenia systemu komunikacyjnego lub pojawił się deficyt bądź niedowład sprawności realizacyjnych [Jastrzębowska, 2003c, s. 37]. W przypadku gdy proces powstawania mowy i jej wzrastania w którymś z aspektów - fonetycznym, gramatycznym, leksykalnym bądź ekspresyjnym - nie następuje zgodnie z normą wiekową, można mówić o opóźnionym rozwoju mowy [Jastrzębowska, Pelc-Pękala, 2003, s. 346].

Jastrzębowska [2003c] zwraca uwagę, że część badaczy dokonujących analizy opóźnionego rozwoju mowy, opisując to zagadnienie, skupia się głównie na objawach albo na przyczynach, a pozostali na patomechanizmie i pochodzeniu tego zjawiska. Opóźniony rozwój mowy według kryterium przyczynowego można podzielić na samoistny oraz niesamoistny [Jastrzębowska, 2003c, s. 41]. Samoistny opóźniony rozwój mowy odnosi się do tych ograniczeń, które są „[...] przejawem dysharmonii rozwoju, wynikających z wolniejszego tempa dojrzewania układu nerwowego bądź niekorzystnego wpływu środowiska" [Jastrzębowska, 2000, s. 82]. Niesamoistny rozwój mowy jest konsekwencją zaburzeń o konkretnym podłożu, na przykład zaburzeń słuchu, upośledzenia umysłowego czy uszkodzenia ośrodkowego układu nerwowego [Stasiak, 2012, s. 355].

O opóźnionym rozwoju mowy można mówić wtedy, gdy konkretny etap rozwoju mowy nie wystąpił w czasie, w którym przyjęto, że powinien się pojawić [Demelowa, 1978; Spionek, 1981; Dilling-Ostrowska, 1982; Zaleski, 1992 i inni]. W innym ujęciu opóźniony rozwój mowy stwierdza się, jeśli przedłuża się proces wykształcania i dojrzewania mowy [Styczek, 1980] albo gdy występują znaczne dysproporcje dotyczące konkretnych podsystemów języka [Spionek, 1981; Kania, 1982; Pruszewicz, 1986] bądź poziomy rozwoju percepcji oraz ekspresji istotnie się od siebie różnią [Zaleski, 1992; Tarkowski, 1993]. Według jeszcze innych autorów o tym zaburzeniu można mówić, gdy występują dysproporcje związane z rozwojem wszystkich czy też poszczególnych aspektów mowy [Sawa, 1990], a zwłaszcza gdy istnieje rozdźwięk między zaawansowaniem rozwoju językowej sprawności systemowej i komunikacyjnej [Grabias, 1997].

Jadwiga Szumska [1982] w swojej klasyfikacji zaburzeń mowy uznaje alalię prolongatę, czyli opóźniony rozwój mowy, za objaw, który może towarzyszyć chorobom i patologiom rozwojowym. Jako jedną z przyczyn rozwojowych zaburzeń wymienia 
zaniedbania środowiskowe. Podobne stanowisko reprezentuje Ewa Dilling-Ostrowska [1982], która do czynników opóźnienia rozwoju mowy dołącza brak okazji do mówienia, niekorzystne warunki środowiskowe i zaburzenia emocjonalne.

Joanna Stasiak [2012, s. 356], wskazując możliwe przyczyny opóźnień w nabywaniu mowy, wymienia - poza czynnikiem dziedzicznym, opóźnionym dojrzewaniem układu neurologicznego w obrębie obszarów korowych lewej półkuli mózgu związanych z mową, chorobami z okresu pre-, peri- i postnatalnego - także ubogą stymulację językową.

Wnioski z niniejszego artykułu pozwolą zweryfikować, czy do przyczyn opóźnionego rozwoju mowy można dodać bardzo popularny obecnie trend, polegający na wczesnym kontakcie dziecka $\mathrm{z}$ urządzeniami multimedialnymi (telefonem, tabletem, komputerem lub telewizorem).

\section{Opóźniony rozwój mowy a afazja}

W międzynarodowej klasyfikacji chorób ICD-10 opóźnienia rozwoju mowy nie wyróżnia się jako oddzielnej kategorii diagnostycznej, co skutkuje brakiem jednokierunkowego podejścia $\mathrm{w}$ diagnozowaniu i pomocy terapeutycznej dzieci z takimi zaburzeniami mowy.

Do 5. roku życia dziecka trudno zauważyć różnicę między opóźnionym rozwojem mowy a afazją rozwojową. Afazja rozwojowa to jedna z postaci dziecięcych zaburzeń mowy pochodzenia centralnego. Definiuje się ją jako nieprawidłowość wyróżniającą się brakiem rozwoju języka, a w efekcie opóźnionym rozwojem mowy [Jastrzębowska, 2003b, s. 83]. Jeśli mowa dziecka od początku rozwija się nieprawidłowo $\mathrm{z}$ uwagi na uszkodzenie centralnego układu nerwowego, używa się terminu afazja rozwojowa. Natomiast gdy zaburzenie powstanie w okresie postnatalnym, stosuje się określenie afazja nabyta [Stasiak, 2012, s. 343]. Zdaniem Joanny Skibskiej w obu zespołach (afazji rozwojowej oraz opóźnionym rozwoju mowy) początkowo może występować brak bądź opóźnienie rozwoju mowy. Dzieci z afazją rozwojową i prostym - samoistnym opóźnionym rozwojem mowy mają prawidłowy słuch, rozwój psychoruchowy, prawidłową pracę narządów mowy, nierzadko występują u nich zaburzenia lateralizacji. Dzieci, które charakteryzuje opóźniony rozwój mowy, po 5. roku życia z reguły zaczynają mówić i szybko nadrabiają opóźnienia, w przeciwieństwie do dzieci z afazją rozwojową [Skibska, 2012, s. 54]. Każde dziecko, u którego stwierdzi się opóźniony rozwój mowy, powinno zostać jak najszybciej otoczone opieką logopedyczną w celu pobudzenia jego rozwoju językowego. W poradniach psychologiczno-pedagogicznych małe dzieci z takimi problemami rzadko mają możliwość uczestniczenia w cotygodniowej, indywidualnej terapii logopedycznej z uwagi na dużą liczbę osób oczekujących na diagnozę i terapię w tym miejscu. Rodzice otrzymują jednak informację o możliwości uzyskania dla swoich dzieci orzeczenia 
o potrzebie kształcenia specjalnego ${ }^{1}$ (gdy dziecko uczęszcza już do przedszkola) lub opinii o wczesnym wspomaganiu rozwoju dziecka ${ }^{2}$ (jest ono realizowane w konkretnych ośrodkach, a kończy się z chwilą rozpoczęcia edukacji szkolnej), które zagwarantują dziecku specjalistyczną pomoc. Wielu rodziców korzysta z tej możliwości i po badaniu psychologicznym oraz logopedycznym przynosi do poradni psychologiczno-pedagogicznej zaświadczenie lekarskie, najczęściej od neurologa, stwierdzające afazję ${ }^{3}$. Większość $z$ tych dzieci ma jedynie opóźniony rozwój mowy, ale na to zaburzenie nie otrzymałyby wsparcia $w$ ramach wczesnego wspomagania rozwoju lub kształcenia specjalnego. Badacze reprezentują pogląd, że nie powinno się biernie czekać, aż samoistny opóźniony rozwój mowy ustąpi [Emiluta-Rozya, 2007; Smoczyńska, 2012]. O tym, że warto zacząć działać, przekonują wyniki badań Magdaleny Smoczyńskiej [2012], która udowodniła, że bardzo mała grupa dzieci (jedynie około 15-25\%), u których w wieku dwóch lat stwierdzono opóźniony rozwój mowy, faktycznie była w stanie po kilku latach porozumiewać się na poziomie swoich pięcio- i sześcioletnich rówieśników.

\section{Nowoczesne technologie}

Współcześni rodzice chcą, by ich dzieci bez trudności potrafiły odnaleźć się w świecie intensywnych zmian technologicznych. Decyzje opiekunów o wczesnym kontakcie dzieci z urządzeniami mobilnymi mogą być oparte na opiniach niektórych

1 Orzeczenie o potrzebie kształcenia specjalnego jest podstawowym dokumentem w edukacji dziecka z niepełnosprawnością. Jest to decyzja administracyjna, którą wydaje się na wniosek rodziców bądź prawnych opiekunów. Podstawa prawna: par. 5 Rozporządzenia Ministra Edukacji Narodowej z dnia 14 września 2017 r. w sprawie orzeczeń i opinii wydawanych przez zespoły orzekające działające w publicznych poradniach psychologiczno-pedagogicznych (Dz.U. z 2017 r., poz. 1743).

2 Opinia o wczesnym wspomaganiu rozwoju dziecka jest dokumentem, w którym znajduje się diagnoza poziomu funkcjonowania dziecka, a także informacje dotyczące kierunków i harmonogramu działań podejmowanych w zakresie wczesnego wspomagania i wsparcia rodziny dziecka. Taki dokument może otrzymać rodzic dziecka, które jeszcze nie rozpoczęło edukacji przedszkolnej lub które uczęszcza do przedszkola. W opisie, jaki znajduje się w tej opinii, uwzględniane jest rozwijanie aktywności i uczestnictwo dziecka w życiu społecznym oraz eliminowanie barier i ograniczeń w środowisku, utrudniających jego funkcjonowanie. Podstawa prawna: par. 4 Rozporządzenia Ministra Edukacji Narodowej z dnia 24 sierpnia 2017 r. w sprawie organizowania wczesnego wspomagania rozwoju dzieci (Dz.U. z 2017 r., poz. 1743).

3 Rozporządzenie Ministra Edukacji Narodowej z dnia 9 sierpnia 2017 r. w sprawie warunków organizowania kształcenia, wychowania i opieki dla dzieci i młodzieży niepełnosprawnych, niedostosowanych społecznie i zagrożonych niedostosowaniem społecznym (Dz.U. z 2017 r., poz. 1578) określa warunki organizowania kształcenia, wychowania i opieki dla dzieci i młodzieży mających orzeczenie o potrzebie kształcenia specjalnego, tj. niepełnosprawnych: niesłyszących, słabosłyszących, niewidomych, słabowidzących, $\mathrm{z}$ niepełnosprawnością ruchową, $\mathrm{w}$ tym $\mathrm{z}$ afazją, $\mathrm{z}$ niepełnosprawnością intelektualną w stopniu lekkim, umiarkowanym lub znacznym, $\mathrm{z}$ autyzmem, w tym z zespołem Aspergera, i z niepełnosprawnościami sprzężonymi, zwanych uczniami niepełnosprawnymi. 
ekspertów o tym, że jeśli nowe technologie używane są w odpowiedni sposób, przynoszą pozytywne efekty. Wspomagają wielozadaniowość, prowadzą do zwielokrotnienia połączeń neuronalnych w mózgu, wspierają procesy asocjacyjne, potęgują efektywność pracy w warunkach, w których pojawia się dużo bodźców [Jędrzejko, 2012]. Problemem jednak jest to, że niewielu rodziców szuka odpowiedzi na pytanie, co oznacza „odpowiedni sposób” posługiwania się przez dziecko na przykład telefonem czy telewizorem. Istnieje związek pomiędzy rodzajem gier oraz bajek i czasem korzystania przez dzieci z nowych technologii a tym, jak się zachowują. Brak kontroli w używaniu komputera czy oglądaniu telewizji powoduje zaburzenia, które dzieli się na zdrowotne i psychiczne. Są to między innymi problemy ze wzrokiem, dolegliwości w obrębie kręgosłupa, karku, szyi, nadgarstków, bóle głowy, a nawet skurcze mięśni [Bednarek, 2006]. Dzieci mogą mieć także problemy z koncentracją, odznaczać się kompulsywnymi zachowaniami, napadami agresji i większą nerwowością [Tanaś, 1993].

Badacze zauważają, że nie powinno się oceniać zbyt wysoko wpływu nowoczesnych technologii (zwłaszcza telefonu, tabletu, komputera, konsoli czy telewizji) na sam proces kształcenia [Lekka-Kowalik, 2001; Morbitzer, 2002; Hędzelek, 2008; Kozielska, 2008], a zwłaszcza wychowywania dzieci.

Współczesne technologie wpływają na postrzeganie świata przez najmłodszych w taki sposób, że często tracą oni poczucie tego, co jest prawdą, a co fikcją. Istnieje duże ryzyko zatracenia się $\mathrm{w}$ cyfrowym świecie, co z kolei prowadzi do uzależnienia oraz różnych konfliktów w środowisku wychowawczym [Błachnio, Gózik, 2007; Furmanek, Osmańska-Furmanek, 2008; Suwara, 2008; Jędrzejko, 2012; Trzcińska-Król, 2014]. Janusz Morbitzer zauważa ogromne ryzyko w sytuacji, w której rodzice nie nadzorują swoich dzieci w trakcie używania komputera. Dzieci, które samodzielnie dobierają treści, wybierają te, które nie mają charakteru dydaktycznego [Morbitzer, 2002; Bożejewicz, Jędrzejko, 2007]. Korzystanie bez ograniczeń z dostępu do bajek i gier multimedialnych może rodzić różne problemy, nawet z naturalnym kształtowaniem się empatii. Nieograniczony kontakt dzieci z multimediami wpływa w sposób bezpośredni na ich zdrowie w wyniku przemęczenia wzroku, braku aktywności ruchowej, wypoczynku, niewłaściwego i nieregularnego odżywiania się, a nawet spożywania nadmiernej ilości cukrów [Jędrzejko, 2012].

Jagoda Cieszyńska-Rożek [2013] uważa, że najmłodsi nie powinni mieć możliwości korzystania z nowoczesnych technologii. Jej zdaniem wpływają one w sposób bezpośredni na funkcje komunikacyjne oraz poznawcze, a także tworzą niewłaściwy model relacji społecznych. Badaczka obserwowała dzieci w wieku od 2 do 4 lat, przebywające na emigracji, które korzystały z komputera. Zauważyła, że nie przejawiały one chęci kontaktu w języku ojczystym ze swoimi opiekunami.

Dziecko zostawione samo przed telewizorem lub $\mathrm{z}$ telefonem w ręku może, po pierwsze, natknąć się na obrazy nieodpowiednie do jego poziomu rozwoju (niezrozumiałe, przerażające, a nawet agresywne), a po drugie może nie mieć potrzeby 
komunikowania się i pełnego funkcjonowania w języku, który jest sposobem odnajdywania się i budowania zdrowych więzi w „realnej” społeczności. To rodzice decydują, kiedy pierwszy raz pozwalają dziecku obejrzeć bajkę i to wyłącznie od nich zależy, jak wiele czasu dzieci spędzą przed urządzeniami elektronicznymi.

Nader często telewizor jest wykorzystywany do tego, żeby dzieci cokolwiek zjadły, aby były spokojne i nie przeszkadzały dorosłym. Zgoda na nieograniczone korzystanie ze współczesnych mediów wynika $\mathrm{z}$ braku stawiania granic najmłodszym. O zagrożeniach powinni być już uświadamiani przyszli rodzice, na przykład podczas zajęć w szkołach rodzenia. Według zaleceń Amerykańskiej Akademii Pediatrii (AAP) całkowity zakaz używania komputera, telefonu, tabletu, konsoli i oglądania bajek w telewizji powinien dotyczyć wszystkich dzieci do 2. roku życia. Zdaniem AAP nadmierne korzystanie $\mathrm{z}$ urządzeń multimedialnych może prowadzić do opóźnionego rozwoju mowy, późniejszych kłopotów z nauką, trudności z koncentracją czy otyłości [American Academy of Pediatrics, 2017]. Kluczowa jest tu współpraca dorosłych, zrozumienie istniejącego problemu oraz ustalenie granic i norm [Kozielska, 2008; Jędrzejko, 2012]. Warto prowadzić przemyślaną edukację medialną, mogącą pomóc rodzinom uzyskać wiedzę, dzięki której najmłodsi nie ponosiliby konsekwencji otwartego dostępu do multimediów [Furmanek, 2005]. Ważne, by osoby mające wiedzę na temat nowoczesnych technologii przeprowadzały prelekcje i rozmowy z rodzicami, uświadamiające im negatywny wpływ urządzeń cyfrowych na rozwój mowy. Dobrze byłoby dzielić się także wiedzą na temat publikacji poruszających zagadnienia uzależnienia od komputera, konsoli, telefonu komórkowego oraz tego, jak internet działa na nasz mózg [Augustynek, 2010; Kozak, 2013; Nicholas, 2013; Hilarie, Kim, 2014; Ogonowska, 2018].

Najczęściej powtarzanym mitem wśród rodziców jest ten, iż dzieci nauczą się z bajek języka obcego. Aby obrazowo obalić tę tezę, wystarczy porównać pierwszy język do fundamentu, który stanowi podstawę domu. Jeśli drugi język będzie ścianą domu, to kiedy nie ma fundamentów lub są one słabe, dom nie może powstać lub być trwały. Dzieci jednojęzyczne, które nie mają zbudowanego systemu językowego w jednym języku, nie są w stanie tworzyć podstaw w drugim. Tak więc bajki nie powodują wzbogacenia języka dziecka o nowe słowa. Do nauczenia się kolejnego języka w przypadku dziecka monolingwalnego potrzebne jest zbudowanie solidnych podstaw w jego głównym języku. Poza tym kluczowy w nauce języka jest bezpośredni kontakt $\mathrm{z}$ drugim człowiekiem i jak największa liczba podejmowanych interakcji, które sprzyjają spontanicznym odpowiedziom, nowym przeżyciom oraz doświadczeniom. 


\section{Badania - opis}

Zainspirowana informacjami, które coraz częściej uzyskiwałam w gabinecie logopedycznym, postanowiłam stworzyć autorskie narzędzie: kartę wywiadu dla rodziców. Analiza wyników danych z wywiadów miała umożliwić wyciągnięcie wniosków dotyczących wpływu między innymi telefonu, telewizji oraz tabletu na rozwój mowy dzieci. Od stycznia do października 2019 roku udało mi się zbadać w Poradni Psychologiczno-Pedagogicznej $\mathrm{nr} 2 \mathrm{w}$ Sosnowcu dwieście dzieci, z których połowa to dzieci z prawidłowym rozwojem mowy, a druga połowa z opóźnionym rozwojem mowy. Wszystkie badane dzieci miały 2,5 roku lub 3 lata. Badanie diagnostyczne standaryzowanym narzędziem - Kartami Oceny Logopedycznej Dziecka [Gruba 2017] - pozwoliło dokonać oceny umiejętności dzieci w zakresie rozumienia i nadawania mowy, reakcji słuchowych, narządów mowy, artykulacji oraz w przypadku trzyletnich dzieci w zakresie umiejętności pragmatyczno-społecznych. Bardzo istotna była bezpośrednia obserwacja zachowań dzieci, co pozwoliło ocenić, czy na przykład deklaracje rodziców nie zaniżają skali zjawiska. Istotne było także pytanie związane z częstotliwością używania przez dzieci tabletu, komputera czy telefonu. Choć poruszane kwestie nie były drażliwe, to na odpowiedzi na część pytań (np. długość czasu spędzanego z urządzeniami mobilnymi) mógł mieć wpływ kontekst społeczny. Oznacza to, że rodzice, wiedząc, że uważa się powszechnie, iż dzieci nie powinny korzystać zbyt długo z urządzeń multimedialnych, często udzielają takiej odpowiedzi, która nie wpłynie negatywnie na ich obraz.

Poniżej znajdują się pytania, które zostały zadane wszystkim rodzicom badanych dzieci.

\section{Wywiad dotyczący rozwoju dziecka do 3. roku życia:}

1. Imię dziecka $\ldots \ldots \ldots \ldots \ldots \ldots \ldots$

2. Wiek dziecka ..................

3. Kto opiekował się dzieckiem do 3. roku życia? (Jeśli dziecko chodziło do żłob$\mathrm{ka}$, to ile godzin dziennie tam spędzało?)

4. Czy dziecko zaczęło siadać, stawać, chodzić o czasie? Czy raczkowało?

- Rozwój ruchowy prawidłowy

- Wystąpiły problemy (Jakie?)

5. Czy dziecko zaczęło wypowiadać pierwsze słowa do ukończenia 2. roku życia, a zdania do ukończenia 3. roku życia? Czy rozwój mowy był prawidłowy?

- Rozwój mowy prawidłowy

- Były problemy (Jakie?) 
6. Od kiedy dziecko ogląda telewizję lub bajki/teledyski na telefonie/tablecie?

7. Czy telewizor w domu jest włączony cały czas? TAK/NIE

8. Czy dziecko bawi się lub spędza dużo czasu w pomieszczeniu, w którym jest włączony telewizor? TAK/NIE

9. Ile mają Państwo w domu telewizorów?

10. Czy w pokoju dziecka jest telewizor? TAK/NIE

11. Czy na co dzień dziecko korzysta $z$ telefonu, komputera lub tabletu? TAK/NIE Jeśli TAK, to ile czasu spędza przed multimediami?

$\begin{array}{ll}20 \text { minut godzinę } & \text { od } 1 \text { do } 2 \text { godzin od } 2 \text { do } 3 \text { godzin } \\ \text { od } 3 \text { do } 4 \text { godzin } & \text { mogłaby/mógłby cały dzień }\end{array}$

12. W jaki sposób komunikuje się dziecko? (tutaj możliwa jest więcej niż jedna odpowiedź)

- Pokazuje palcem

- Ciągnie rodzica/opiekuna do rzeczy, którą chce

- Mówi „po swojemu”

- W inny sposób (Jaki?)

13. Czy obce osoby rozumieją dziecko? TAK/NIE

14. Jak reaguje dziecko, gdy inni go nie rozumieją?

15. Czy dziecko jest odrzucane przez rówieśników? TAK/NIE

16. Czy dziecko bawi się elektronicznymi zabawkami? TAK/NIE

17. Czy dziecko lubi słuchać, gdy czyta mu się książki? TAK/NIE

18. Jak długo dziecko jest w stanie skupić się podczas czytania mu książki bądź wspólnego patrzenia na obrazki?

19. Czy osoby, które przebywają z dzieckiem, codziennie mu śpiewają, mówią rymowanki, krótkie wierszyki? TAK/NIE

20. Czy występowały jakieś niepokojące Państwa (opiekunów) zachowania? Czy coś Państwa martwiło w rozwoju dziecka?

21. Czy dziecko rozumie polecenia wydawane przez rodziców, opiekunów? TAK/NIE

22. Czy dziecko chorowało na zapalenie ucha bądź miało inne problemy związane ze słuchem? TAK/NIE

23. Czy dziecko miało badany/kontrolowany słuch u lekarza? TAK/NIE

24. Czy dziecko używa/używało smoczka uspokajacza? TAK/NIE Jeśli TAK, jak długo? 


\section{Wyniki badań}

Wyniki badań 4 dowiodły, że w przypadku prawidłowego rozwoju mowy ponad $86 \%$ dzieci nie oglądało telewizji lub bajek na telefonie czy tablecie do 2. roku życia. Wyniki dla opóźnionego rozwoju mowy pokazały, że więcej niż 76\% najmłodszych oglądało bajki przed 2. rokiem życia. Rodziców dzieci z opóźnionym rozwojem mowy należałoby zapoznać ze wskazówkami Amerykańskiej Akademii Pediatrii, która nie zaleca kontaktu z telewizją czy tabletem dzieciom przed 2. rokiem życia.

Od kiedy dziecko ogląda telewizję lub bajki na telefonie/tablecie?

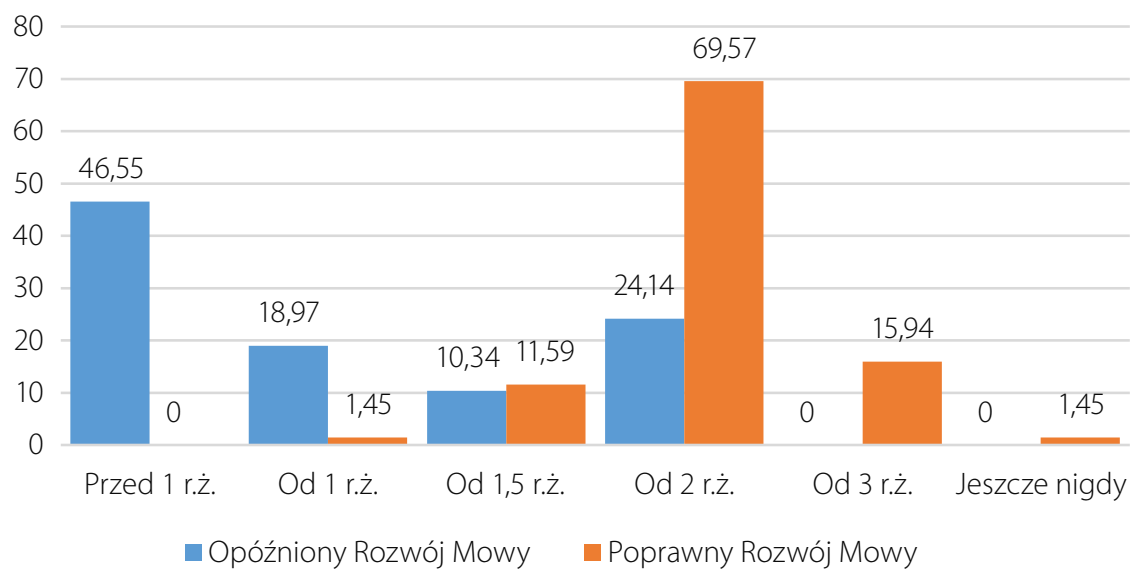

Wykres 1. Pierwszy kontakt dziecka z multimediami, wywiad dotyczący rozwoju dziecka do 3. roku życia (\%)

\section{Źródło: opracowanie własne na podstawie wyników badań.}

Spędzanie przez dziecko czasu w pomieszczeniu, w którym jest włączony telewizor, powoduje wiele negatywnych konsekwencji. Po pierwsze, dzieci nie koncentrują się na żywej mowie, kierowanej do nich w tym czasie na przykład przez rodziców. Po drugie, nadmiar bodźców dźwiękowych i wizualnych wzmacnia pobudzenie najmłodszych i uruchamia prawą półkulę mózgu. Nie są to warunki sprzyjające skupieniu się na słowach. Wyniki badań wykazały, że aż $74 \%$ dzieci z opóźnionym rozwojem mowy spędzało dużo czasu w pomieszczeniu, w którym był włączony telewizor. Z kolei w grupie dzieci z prawidłowym rozwojem mowy $90 \%$ nie bawiło się $\mathrm{z}$ włączonym telewizorem $\mathrm{w}$ tle.

\footnotetext{
$4 \mathrm{~W}$ tym miejscu zostaną omówione tylko wybrane wyniki badań, istotne z punktu widzenia tego
} artykułu. 
Czy dziecko bawi się lub spędza dużo czasu w pomieszczeniu,

w którym jest włączony tv?

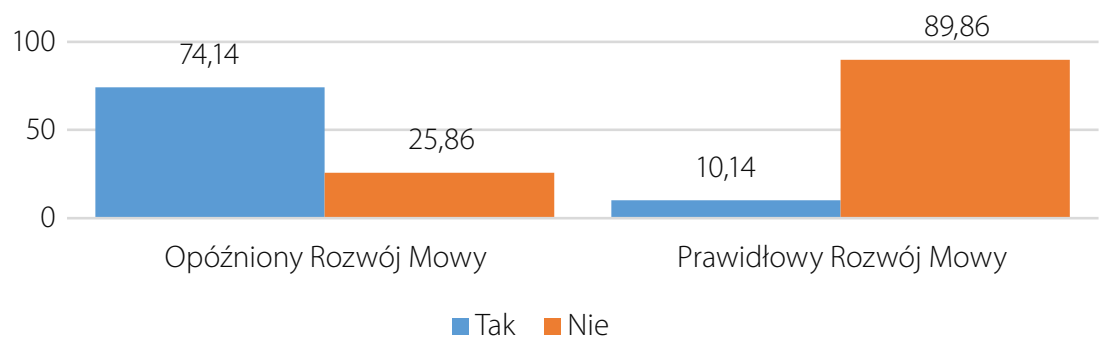

Wykres 2. Zabawa w pomieszczeniu, w którym znajduje się włączony telewizor, wywiad dotyczący rozwoju dziecka do 3. roku życia (\%)

Źródło: opracowanie własne na podstawie wyników badań.

Korzystanie na co dzień z telefonu, komputera i tabletu także ma niebagatelny wpływ na rozwój mowy. Dzieci wpatrzone w ekran telefonu czy tabletu z grą, bajką lub filmem nie powiększają w żaden sposób swojego zasobu słów. Wielu rodziców jest dumnych, gdy ich pociecha lepiej od nich radzi sobie z telefonem czy tabletem. Jeżeli dziecko nie mówi, a dostaje wzmocnienie w postaci narzędzia multimedialnego, które nie wymaga od niego powtarzania, mówienia, komunikowania się, utrwalone zostają te nawyki, które hamują proces przyswajania mowy. Badanie potwierdziło, że w grupie z opóźnionym rozwojem mowy ponad $76 \%$ dzieci na co dzień korzystało z wcześniej wspomnianych urządzeń multimedialnych. Wśród dzieci z prawidłowym rozwojem mowy $71 \%$ nie używało codziennie telefonu, tabletu czy komputera.

Czy na co dzień dziecko korzysta z telefonu, komputera lub tabletu?

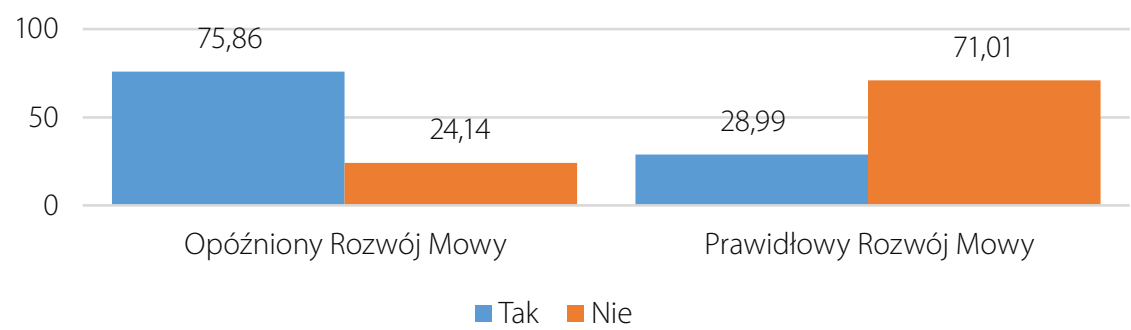

Wykres 3. Codzienne korzystanie z telefonu, komputera lub tabletu, wywiad dotyczący rozwoju dziecka do 3. roku życia (\%)

Źródło: opracowanie własne na podstawie wyników badań.

W przypadku gdy dziecko nie potrafi mówić lub mówi mało i bardzo niewyraźnie, często jest odrzucane przez kolegów. Rówieśnicy nie chcą bawić się z kimś, kogo nie rozumieją, kto bywa agresywny, krzyczy, piszczy, zachowuje się nieobliczalnie. Ponad 34\% rodziców wskazało, że ich dziecko z opóźnionym rozwojem mowy jest 
odtrącane przez swoich kolegów. Tymczasem najmłodsi z prawidłową mową bardzo rzadko $(1,45 \%)$ doświadczali odrzucenia. Takie zachowania mogą wpłynąć na późniejszą samoocenę i otwartość dziecka, a także zdolność do nawiązywania w przyszłości relacji i kontaktów interpersonalnych.

Czy dziecko jest odrzucane przez rówieśników?

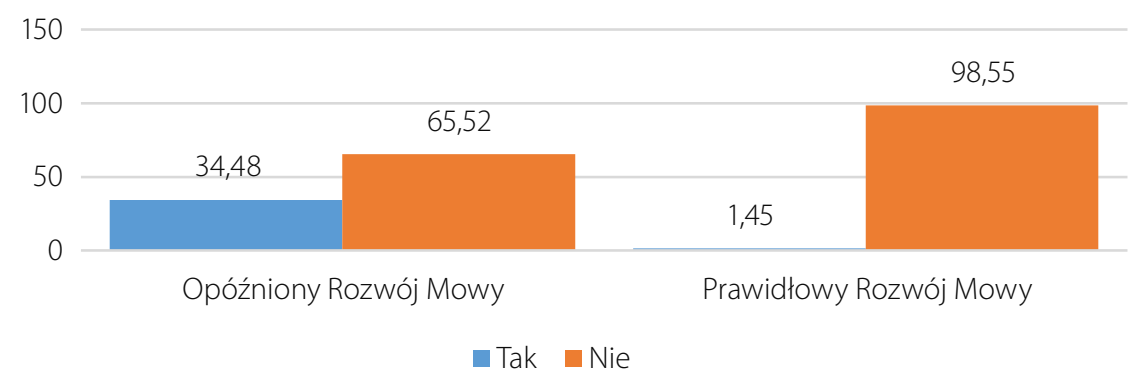

Wykres 4. Odrzucenie przez rówieśników, wywiad dotyczący rozwoju dziecka do 3. roku życia (\%) Źródło: opracowanie własne na podstawie wyników badań.

Rodzice często zapominają, że mowy uczymy się przez naśladowanie, przebywanie $\mathrm{z}$ drugim człowiekiem, zabawę. Stymulowanie pamięci i uwagi słuchowej ma znaczny wpływ na rozwój mowy. Ponad $86 \%$ dzieci z prawidłową mową słyszało od swoich rodziców i opiekunów codziennie piosenki, krótkie rymowanki oraz wierszyki. Tylko $48 \%$ najmłodszych z opóźnionym rozwojem mowy było pobudzanych werbalnie w taki sposób.

Czy osoby, które przebywają z dzieckiem codziennie mu śpiewają, mówią rymowanki, krótkie wierszyki?

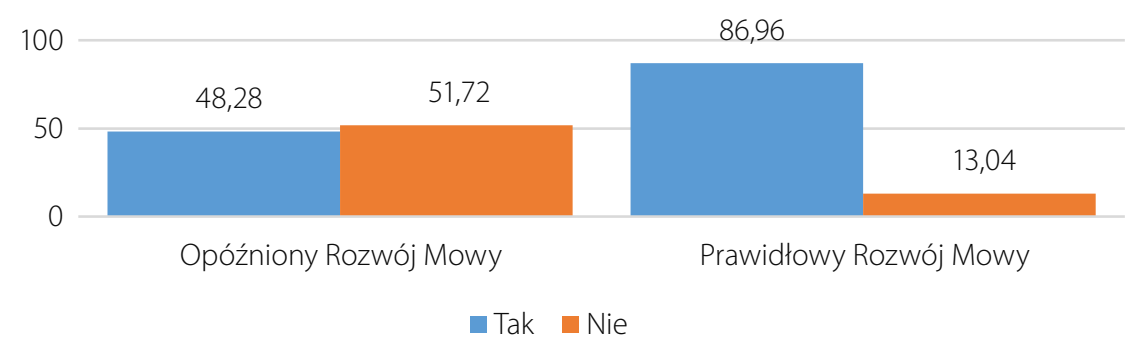

Wykres 5. Stymulowanie dziecka przez najbliższe otoczenie, wywiad dotyczący rozwoju dziecka do 3. roku życia (\%)

Źródło: opracowanie własne na podstawie wyników badań.

Aby dowiedzieć się jak najwięcej o rozwoju mowy badanej grupy, w wywiadzie zapytałam o czytanie najmłodszym książek przez rodziców. Większość dzieci z prawidłowym rozwojem mowy - ponad 94\% - znajdowała przyjemność w słuchaniu lektur. Natomiast tylko 59\% dzieci z opóźnionym rozwojem mowy lubiło słuchać, 
gdy czytano im książki. Kolejne pytanie z wywiadu dotyczyło tego, jak długo dziecko jest w stanie skupić się podczas czytania mu książki bądź wspólnego oglądania obrazków. Rodzice maluchów z prawidłowym rozwojem mowy informowali, że ich dzieci chętnie słuchały dłuższych opowiadań i potrafiły robić to z zainteresowaniem od 20 do 30 minut. W przypadku grupy z opóźnionym rozwojem mowy rodzice przyznawali, że dzieci podczas lektury koncentrowały się bardzo krótko - od minuty do maksymalnie pięciu.

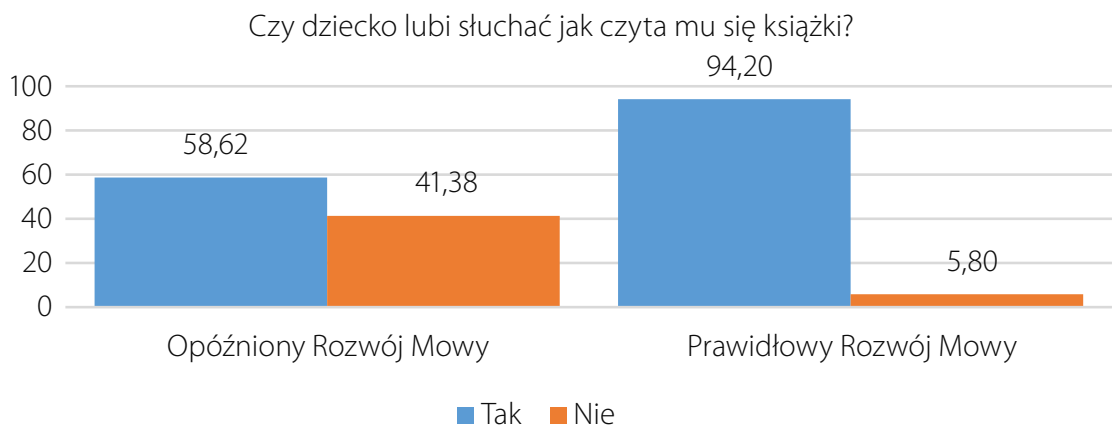

Wykres 6. Czytanie książek, wywiad dotyczący rozwoju dziecka do 3. roku życia (\%)

Źródło: opracowanie własne na podstawie wyników badań.

Pytanie o to, czy obce osoby rozumieją dziecko, pokazało z jednej strony skalę problemu ( $80 \%$ najmłodszych z opóźnionym rozwojem mowy nie było rozumianych przez osoby inne niż bliscy), a z drugiej także świadomość opiekunów dotyczącą tego, jak są odbierani ich podopieczni. Aż $20 \%$ rodziców dzieci z opóźnionym rozwojem mowy nie zdawało sobie sprawy z faktu, że jest mało prawdopodobne, by maluch, który nie mówi, a komunikuje się jedynie gestem lub krzykiem, miał możliwość efektywnego przekazania swoich myśli, pragnień czy zamierzeń.

Czy obce osoby rozumieją dziecko?

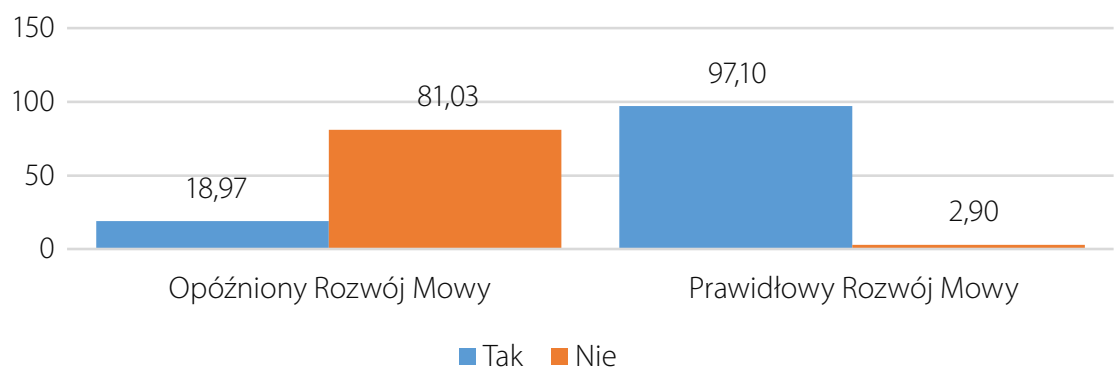

Wykres 7. Tworzenie zrozumiałych komunikatów przez dziecko, wywiad dotyczący rozwoju dziecka do 3. roku życia (\%) 


\section{Podsumowanie}

Współczesność zaskakuje nowinkami technologicznymi i udogodnieniami, w szczególności technicznymi, które ułatwiają funkcjonowanie oraz dają wiele możliwości rozwijania wszelkich umiejętności. Z punktu widzenia rozwoju dziecka, zwłaszcza jego mowy, zbyt szybkie „zanurzenie” malucha w świat nowych technologii może mieć istotny wpływ nie tylko na sam rozwój mowy, ale także na jego ogólny rozwój psychofizyczny. Młodzi rodzice nie spędzają ze swoimi dziećmi i rodzinami czasu w taki sposób, w jaki sami korzystali z niego w dzieciństwie. Brakuje także chwil na rozmowę, na mówienie do najmłodszych w sposób, który mogliby naśladować. Obecnie przewagę zyskały bodźce wzrokowe - ekrany telewizorów, tabletów, komputerów i innych urządzeń. To one wzięły górę nad tradycyjnymi zabawami, spontaniczną wymianą myśli i spędzaniem czasu na świeżym powietrzu. Także rolę zabawek, książek, kołysanek i wierszyków przejęły telewizory i telefony, w których można znaleźć bajki, gry i programy wabiące walorami edukacyjnymi. W efekcie większość trzylatków przekraczających próg przedszkola jest mocno przestymulowana obrazami z wyżej wspomnianych urządzeń, co powoduje problemy z prawidłową komunikacją, mimo niemal doskonałej umiejętności wyszukiwania filmów na telefonie czy tablecie.

Uczenie się mówienia uważa się za:

\section{[...] największy skok intelektualny w życiu jednostki, otwiera ono przed dzieckiem nowy świat, świat pytań, rozumowania, komunikacji społecznej i opinii [...], które nadają ogrom- nego przyspieszenia wszystkim innym rodzajom uczenia się i sprawiają, że dziecko zaczyna się nagle wydawać w pełni rozwiniętą osobą [Eliot, 2003, s. 484].}

Aby rozwój mowy dziecka przebiegał prawidłowo, należy pamiętać o wzajemnych relacjach funkcji poznawczych, sprawności językowych, sfery intelektualnej i emocjonalnej. Mając świadomość istnienia tych korelacji, warto upowszechniać wiedzę oraz wyniki badań wśród rodziców. Należy informować ich, kiedy i jak udostępniać media elektroniczne najmłodszym z pożytkiem dla ich rozwoju 5 . Najważniejsze, by propagować trend nieudostępniania tabletu, telefonu, a nawet bajek w telewizji dzieciom przed 2. rokiem życia. W momencie gdy dziecko wkroczy już w świat nowych technologii, należy pamiętać o ustalaniu zasad korzystania $\mathrm{z}$ nich i egzekwować wyznaczone reguły, by dać dziecku poczucie bezpieczeństwa i mieć pewność, że pozytywnie wpływa się na jego rozwój.

5 Fundacja Dajemy Dzieciom Siłę dzieli się z rodzicami takimi informacjami, realizując od 2015 roku kampanię społeczną pod hasłem „Mama, tata, tablet” (http://mamatatatablet.pl/). Kampania \#ZARAZ Fundacji Dwa Ognie także pokazuje, czym skutkuje „zanurzenie” w świecie cyfrowym i odkładanie wszystkiego, a szczególnie relacji z bliskimi, na później. 
Literatura

American Academy of Pediatrics, 2017, Handheld screen time linked with speech delays in young children, ScienceDaily, https://www.sciencedaily.com/releases/2017/05/170504083141.htm (dostęp: 12.01.2020).

Augustynek A., 2010, Uzależnienia komputerowe. Diagnoza, rozpowszechnienie, terapia, Warszawa: Wydawnictwo Difin.

Bednarek J., 2006, Zagrożenia w cyberprzestrzeni, [w:] M. Jędrzejko (red.), Patologie społeczne, Pułtusk: Wyższa Szkoła Humanistyczna im. Aleksandra Gieysztora, s. 83-148.

Błachnio A., Gózik A., 2007, Psychologiczne determinanty uzależnienia od Internetu, [w:] M. Sokołowski (red.), Oblicza Internetu. Architektura komunikacyjna Sieci, Elbląg: Państwowa Wyższa Szkoła Zawodowa w Elblągu, s. 207-218.

Bożejewicz W., Jędrzejko M., 2007, Gry komputerowe i sieciowe jako stymulator zachowań agresywnych dzieci i młodzieży, Pułtusk: Wydawnictwo Akademii Humanistycznej im. Aleksandra Gieysztora.

Cieszyńska-Rożek J., 2013, Zaburzenia rozwoju języka polskich dzieci za granica, https://docplayer .pl/5032300-Zaburzenia-rozwoju-jezyka-polskich-dzieci-za-granica.html (dostęp: 27.11.2019).

Demelowa G., 1978, Minimum logopedyczne nauczyciela przedszkola, Warszawa: Wydawnictwa Szkolne i Pedagogiczne.

Dilling-Ostrowska E., 1982, Rozwój i zaburzenia mowy u dzieci w zależności od stopnia dojrzałości układu nerwowego, [w:] J. Szumska (red.), Zaburzenia mowy u dzieci, Warszawa: Państwowy Zakład Wydawnictw Lekarskich, s. 18-30.

Eliot L., 2003, Co tam się dzieje? Jak rozwija się mózg i umysł w pierwszych pięciu latach życia, Poznań: Wydawnictwo Media Rodzina.

Emiluta-Rozya D., 2007, Opóźniony rozwój mowy a opóźnienie rozwoju mowy, „Poradnik Językowy", z. 8, s. 54-65.

Furmanek M., 2005, Edukacja medialna - edukacja dzieci i rodziców, [w:] S. Juszczyk, I. Polewczyk (red.), Dziecko w świecie wiedzy, informacji i komunikacji [materiały konferencyjne], Katowice - Toruń: Wydawnictwo Adam Marszałek, s. 311-322.

Furmanek M., Osmańska-Furmanek W., 2008, Cyfrowy świat dziecka - nowe obszary badawcze, [w:] T. Lewowicki, B. Siemieniecki (red.), Media w edukacji - szanse i zagrożenia, Toruń: Wydawnictwo Adam Marszałek, s. 40-47.

Grabias S., 1997, Mowa i jej zaburzenia, „Audiofonologia”, t. 10, s. 9-36.

Grabias S., 2014, Teoria zaburzeń mowy. Perspektywy badań, typologie zaburzeń, procedury postępowania logopedycznego, [w:] S. Grabias, M. Kurkowski (red.), Logopedia. Teoria zaburzeń mowy, Lublin: Wydawnictwo Uniwersytetu Marii Curie-Skłodowskiej, s. 15-71.

Gruba J., 2017, KOLD (Karty Oceny Logopedycznej Dzieci), Gliwice: Wydawnictwo KOMLOGO.

Hędzelek M., 2008, Uzależnienie od Internetu - zasięg, formy, zagrożenia, [w:] B. Płonka-Syroka, M. Staszczak (red.), E-kultura, e-nauka, e-społeczeństwo, Wrocław: Oficyna Wydawnicza Arboretum, s. 267-282.

Hilarie C., Kim M., 2014, Dzieci konsoli. Uzależnienie od gier, Poznań: Wydawnictwo Media Rodzina.

Jastrzębowska G., 2000, Istota i klasyfikacje opóźnień w rozwoju mowy-przegląd stanowisk, „Logopedia”, nr 28, s. 69-84.

Jastrzębowska G., 2003a, Wprowadzenie. Problemy terminologiczne i definicyjne, [w:] T. Gałkowski, G. Jastrzębowska (red.), Logopedia. Pytania i odpowiedzi - podręcznik akademicki, t. 2, Opole: Wydawnictwo Uniwersytetu Opolskiego, s. 9-36. 
Jastrzębowska G., 2003b, Afazja, dysfazja dziecięca, [w:] T. Gałkowski, G. Jastrzębowska (red.), Logopedia. Pytania i odpowiedzi - podręcznik akademicki, t. 2, Opole: Wydawnictwo Uniwersytetu Opolskiego, s. 83-119.

Jastrzębowska G., 2003c, Opóźnienie rozwoju mowy - przejaw nieprawidłowości rozwojowych, [w:] T. Gałkowski, G. Jastrzębowska (red.), Logopedia. Pytania i odpowiedzi-podręcznik akademicki, t. 2, Opole: Wydawnictwo Uniwersytetu Opolskiego, s. 37-65.

Jastrzębowska G., Pelc-Pękala O., 2003, Diagnoza i terapia opóźnionego rozwoju mowy, [w:] T. Gałkowski, G. Jastrzębowska (red.), Logopedia. Pytania i odpowiedzi-podręcznik akademicki, t. 2, Opole: Wydawnictwo Uniwersytetu Opolskiego, s. 346-362.

Jędrzejko M., 2012, Dzieci i nowe multimedia (szanse - wyzwania - zagrożenia), WarszawaMilanówek-Dąbrowa Górnicza: Mazowieckie Centrum Profilaktyki Uzależnień, Studio Poligraficzne Edytorka.

Kamińska D., 2011, Wpływ formuly lateralizacji na kształtowanie się systemu fonetyczno-fonologicznego, [w:] M. Michalik (red.), Biologiczne uwarunkowania rozwoju i zaburzeń mowy. Nowa logopedia, t. 2, Kraków: Wydawnictwo Collegium Columbinum, s. 85-95.

Kania J.T., 1982, Szkice logopedyczne, Warszawa: Wydawnictwa Szkolne i Pedagogiczne.

Kozak S., 2013, Patologia fonoholizmu: przyczyny, skutki i leczenie uzależnienia dzieci i młodzieży od telefonu komórkowego, Warszawa: Wydawnictwo Difin.

Kozielska M., 2008, Edukacja wobec zagrożeń technologii informacyjnych, [w:] T. Lewowicki, B. Siemieniecki (red.), Media w edukacji - szanse i zagrożenia, Toruń: Wydawnictwo Adam Marszałek, s. 198-206.

Lekka-Kowalik A., 2001, Ukryte założenia idei społeczeństwa informacyjnego, [w:] T. Zasępa (red.), Internet. Fenomen społeczeństwa informacyjnego, Częstochowa: Wydawnictwo Edycja Świętego Pawła, s. 179-194.

Morbitzer J., 2002, Mity edukacji wspieranej komputerowo (czyli 7 grzechów głównych EWK), [w:] J. Morbitzer (red.), Techniki komputerowe w przekazie edukacyjnym, XII Ogólnopolskie Sympozjum Naukowe, Kraków: Wydawnictwo Naukowe Akademii Pedagogicznej, s. 177-187.

Nicholas C., 2013, Ptytki umyst. Jak internet wplywa na nasz mózg, Gliwice: Wydawnictwo Helios - Onepress.

Ogonowska A., 2018, Uzależnienia medialne. Uwarunkowania, leczenie, profilaktyka, Kraków: Wydawnictwo Edukacyjne.

Pruszewicz A., 1986, Zaburzenia głosu i mowy, [w:] E. Kossowska (red.), Pediatria. Otolaryngologia wieku rozwojowego, Warszawa: Wydawnictwo PZWL.

Rozporządzenie Ministra Edukacji Narodowej z dnia 9 sierpnia 2017 r. w sprawie warunków organizowania kształcenia, wychowania i opieki dla dzieci i młodzieży niepełnosprawnych, niedostosowanych społecznie i zagrożonych niedostosowaniem społecznym (Dz.U. z 2017 r., poz. 1578), http://isap.sejm.gov.pl/isap.nsf/DocDetails.xsp?id=WDU20170001578 (dostęp: 12.10.2019).

Rozporządzenie Ministra Edukacji Narodowej z dnia 24 sierpnia 2017 r. w sprawie organizowania wczesnego wspomagania rozwoju dzieci (Dz.U. z 2017 r., poz. 1635), http://isap.sejm.gov.pl /isap.nsf/DocDetails.xsp?id=WDU20170001635 (dostęp: 12.10.2019).

Rozporządzenie Ministra Edukacji Narodowej z dnia 14 września 2017 r. w sprawie orzeczeń i opinii wydawanych przez zespoły orzekające działające w publicznych poradniach psychologiczno-pedagogicznych (Dz.U. z 2017 r., poz. 1743), http://isap.sejm.gov.pl/isap.nsf /DocDetails.xsp?id=WDU20170001743 (dostęp: 12.10.2019).

Sawa B., 1990, Dzieci z zaburzeniami mowy, Warszawa: Wydawnictwa Szkolne i Pedagogiczne. Skibska J., 2012, Afazja dziecięca, [w:] J. Skibska, D. Larysz (red.), Neurologopedia w teorii i praktyce. Wybrane zagadnienia diagnozy i terapii dziecka, Bielsko-Biała: Wydawnictwo Naukowe Akademii Techniczno-Humanistycznej, s. 48-78. 
Smoczyńska M., 2012, Opóźniony rozwój mowy a ryzyko SLI. Co wyniki badań podłużnych mówią nam o potrzebie wczesnej interwencji logopedycznej?, [w:] J. Porayski-Pomsta, M. Przybysz-Piwko (red.), Interwencja logopedyczna, Warszawa: Wydawnictwo Elipsa, s. 13-38.

Spionek H., 1981, Zaburzenia rozwoju uczniów a niepowodzenia szkolne, Warszawa: Państwowe Wydawnictwo Naukowe.

Stasiak J., 2012, Alalia. Perspektywy opisu, [w:] S. Grabias, M. Kurkowski (red.), Logopedia. Teoria zaburzeń mowy, Lublin: Wydawnictwo Uniwersytetu Marii Curie-Skłodowskiej, s. 337-358.

Styczek I., 1980, Logopedia, Warszawa: Państwowe Wydawnictwo Naukowe.

Suwara M., 2008, O nowej wychowawczej roli Internetu, [w:] T. Lewowicki, B. Siemieniecki (red.), Media w edukacji - szanse i zagrożenia, Toruń: Wydawnictwo Adam Marszałek, s. 112-117.

Szumska J., 1982, Zaburzenia mowy u dzieci, Warszawa: Państwowy Zakład Wydawnictw Lekarskich.

Tanaś M., 1993, Medyczne skutki uboczne kształcenia wspomaganego komputerowo, „Toruńskie Studia Dydaktyczne", nr 3(II), s. 127-132.

Tarkowski Z., 1993, Rozwijanie mowy dziecka. Program terapeutyczno-stymulacyjny, Lublin: Wydawnictwo „Orator”.

Trzcińska-Król M., 2014, Media i cyberprzestrzeń, [w:] S. Kuruliszwili (red.), Technologie informacyjne a zmiany wspótczesnej edukacji, Kraków: Oficyna Wydawnicza „Impuls”, s. 23-24.

Zaleski T., 1992, Opóźniony rozwój mowy, Warszawa: Państwowy Zakład Wydawnictw Lekarskich.

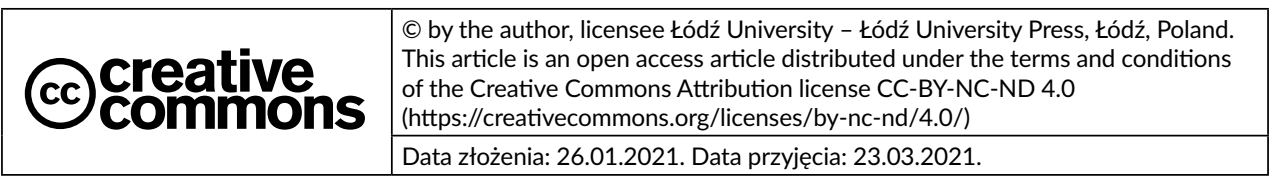

